\begin{tabular}{cc|c}
\hline Tar. Bil. Der. & Tarm Bilimleri Dergisi & Journal of Agricultural Sciences \\
& $\begin{array}{c}\text { Dergi web sayfası: } \\
\text { www.agri.ankara.edu.tr/dergi }\end{array}$ & Journal homepage: \\
& www.agri.ankara.edu.tr/journal
\end{tabular}

\title{
Modelling Indoor Environmental Conditions in a Commercial Broiler House
}

\author{
Erdem KÜÇÜKTOPCU'a, Bilal CEMEK ${ }^{\mathrm{a}}$ \\ ${ }^{a}$ University of Ondokuz Mayls, Faculty of Agriculture, Department of Agricultural Structures and Irrigation, Samsun, TURKEY
}

\author{
ARTICLE INFO \\ Research Article \\ Corresponding Author: Bilal CEMEK, E-mail: bcemek@omu.edu.tr, Tel: +90 (538) 2260482 \\ Received: 25 June 2018, Received in Revised Form: 11 September 2018, Accepted: 26 September 2018
}

\begin{abstract}
Turkey's poultry industry has experienced significant growth in recent years, resulting in the construction of many new production facilities. It is important to maintain optimum environmental conditions for a profitable production. In this study, temperature, relative humidity and air velocity distribution inside a broiler house were analysed. Computational Fluid Dynamics (CFD) simulations (numerical method) and direct measurements (experimental method) were used to determine the appropriate indoor environmental conditions. Simulated values were validated by comparison with the measured values using the normalised mean square error (NMSE). The measured and predicted parameters of temperature, relative humidity and air velocity at birds' height, human height, and roof height upon comparison gave average NMSE values of $0.139,0.181$ and 0.090 , respectively. The results showed a good agreement between simulated and measured values as obtained NMSE values were less than 0.25 . In conclusion, CFD simulation can be used as an alternative method for the analysis of poultry house indoor environment. A better understanding of indoor environment conditions in poultry house provides useful information for manufacturers and end users for better management decisions.
\end{abstract}

Keywords: Broiler house; CFD modelling; Temperature; Relative humidity; Air velocity

(C) Ankara Üniversitesi Ziraat Fakültesi

\section{Introduction}

In recent years, Turkey's poultry industry has become the fastest emerging and growing industry. The industry constitutes a $2 \%$ share of the world poultry production market, with about 1.900 million tons per year and aims to be the world leading chicken industry in the next decade (USDA 2016). This can be accomplished through not only planning the appropriate genetic breeding programs (Leeson \& Summers 2010), but also ensuring availability of suitable environmental conditions (indoor and outdoor) for birds.
During planning and designing of poultry houses, the birds' optimum environmental conditions (indoor) and regional climatic data (outdoor) are important factors to be considered for effective poultry production. Environmental conditions inside poultry houses greatly affect the productivity of the poultry facility. Chickens are very sensitive animals which are affected by temperature (Song \& King 2015), light (Deep et al 2010), relative humidity (Xiong et al 2017) and air exchange fluctuations (Furlan et al 2000) during all rearing phases. Therefore, it is very important to consider environmental conditions and ensure proper design 
of ventilation system in the construction of a poultry house. High summer temperatures and extreme winter conditions greatly affect chicken production and these climatic factors also need to be considered for planning and designing of the poultry house.

The main reasons for the high death rates of broilers are high summer temperatures and humidity values. These deaths accompany considerable economic losses for poultry facilities. In recent years, there have been great efforts to improve the welfare of birds by establishing mechanical ventilation systems in poultry houses (Vizzier Thaxton et al 2016). Despite this solution, the problems arising from the thermal stress are yet to be resolved. Therefore, visualisation of air distribution within the poultry houses comes into prominence.

In agricultural structures two common methods exists to determine the appropriate environmental conditions, which are direct measurements of the conditions using electronic devices and Computational Fluid Dynamics (CFD) techniques (Bustamante et al 2013). The CFD software is often used for the analysis of fluid-related materials nowadays.

It is possible to determine indoor environmental conditions using various equipment and instruments. However, for large production facilities, it is not always easy to collect data using aforementioned instruments and methods as they are time consuming, labour intensive, costly and prone to human error. In addition, since measurements are conducted at regular intervals (grids) the results may not necessarily be representative of the entire house conditions, thus making the accurate prediction of stress areas inside the building difficult.

Because of these drawbacks encountered during direct measurement, CFD techniques can be used as an alternative to determine indoor environmental conditions. The CFD method allows solving of numerically difficult, long and complex equations by means of a computer and analysing the distribution of desired parameters associated with the flow (Bates et al 2005). The CFD simulations not only save time and labour, but also enable visual analysis of the poultry house indoor environmental conditions.

Although CFD techniques are widely used in different fields of engineering (such as mechanical, environmental, aerospace engineering), there are few detailed studies performed for the determination of indoor environmental conditions of poultry houses (Bustamante et al 2013; Bustamante et al 2015; Rojano et al 2015). On the other hand, validation of simulation models with experimental data is essential for reliable predictions.

Based on these facts, the distribution of air temperature, relative humidity and air velocity inside the broiler house were investigated using two methodologies, namely, direct measurement by instrumentation and CFD simulation program. Firstly, air temperature, relative humidity and air velocity were measured at certain number of fixed points and at different heights of a broiler house (experimental method) in Samsun province, Turkey. Then, the collected data were analysed, and findings were compared to those obtained from CFD techniques (numerical method). Finally, the CFD simulation results were used to reconstruct indoor environmental conditions such as stagnant and stress zones of broiler house in the form of visual simulations.

\section{Material and Methods}

\subsection{The building}

Measurements and simulations were carried out at a commercial broiler house located in Samsun province (Northern Hemisphere, Latitude $41^{\circ} 70^{\prime}$, Longitude $36^{\circ} 30^{\prime}$ ) in northern Turkey. The house was lean concrete-floored with a breeding area of $1260 \mathrm{~m}^{2}(90 \mathrm{~m} \times 14 \mathrm{~m})$, designed for 22.000 broilers yielding a stocking density of 14 to 17 birds $\mathrm{m}^{-2}$. Basic geometric dimensions of the house are as follows: length, $90 \mathrm{~m}$; width, $14 \mathrm{~m}$; sidewall height, $2.70 \mathrm{~m}$; maximum height, $4.40 \mathrm{~m}$. Sawdust is used as a litter material. Feeding, watering, lighting, heating and ventilation are controlled automatically. The broiler house is equipped with eight big (diameter $1.38 \mathrm{~m}$ ) 
and five small exhaust fans (diameter $0.92 \mathrm{~m}$ ). At the time of data collection ( $4^{\text {th }}$ week), only two big fans located in the centre were operational. The house has sixty-six air inlets measuring $32.50 \times 52.50 \mathrm{~cm}$, placed along with the side walls. The heating system comprised an external heat source with a dual-tube system and outlet air temperature of $75^{\circ} \mathrm{C}$.

\subsection{Experimental method}

The vertical plane was defined based on three measurement positions from the floor, that are, birds' height $(\mathrm{BH})$, human height $(\mathrm{HH})$ and roof height (RH), placed at $0.25 \mathrm{~m}, 1.80 \mathrm{~m}$ and $2.50 \mathrm{~m}$, respectively (Figure 1). To examine distribution of inside air temperature, relative humidity and air velocity, measurements were taken at fourth weeks of growing seasons (May 2016). A total of fifty-nine measurements were taken from different locations in the building including forty-two at $\mathrm{BH}$, fourteen at $\mathrm{HH}$ and three at RH (Figure 2).

To monitor indoor temperature and relative humidity distribution, fifty-nine relative humidity and temperature data loggers (KC 320B, NDI Instrument and Hand Tools, Cheltenham Australia) with a resolution of $\pm 0.1 \%$ and $\pm 0.1{ }^{\circ} \mathrm{C}$ respectively, were positioned as indicated in Figure 3. Measurements were automatically recorded at an interval of 30 minutes by data loggers. Outdoor air temperature and relative humidity were monitored by a data logger that was placed beneath the outside eaves of the building for protection against direct sunlight and rain.

In addition to above-mentioned fifty-nine measurement points, air velocity measurements were also taken from each of the air inlet points and fan areas located in the building. Air velocity was measured using airflow anemometer (DCFM8906, General Tools \& Instruments, New York, USA). The instrument gives the instantaneous value of the measured air velocity. For the correct measurement (to minimize human error) the operation has been replicated three times (10 $\mathrm{s}$ intervals) for each point. The average of three obtained velocity values was considered as the final result (Awbi 2003). During the experiment, a traverse was run across the fan inlet measuring air velocity using a hand-held anemometer at 9 specific coordinates as highlighted by Wheeler \& Bottcher (1995). The mean air velocities were obtained at each air inlet from 25 measurements per inlet (ASHRAE 2009). A thermal camera (Testo 875-2i, Testo AG, Lenzkirch, Germany) was used to measure the surface temperatures of each wall, roof, heater and broilers.

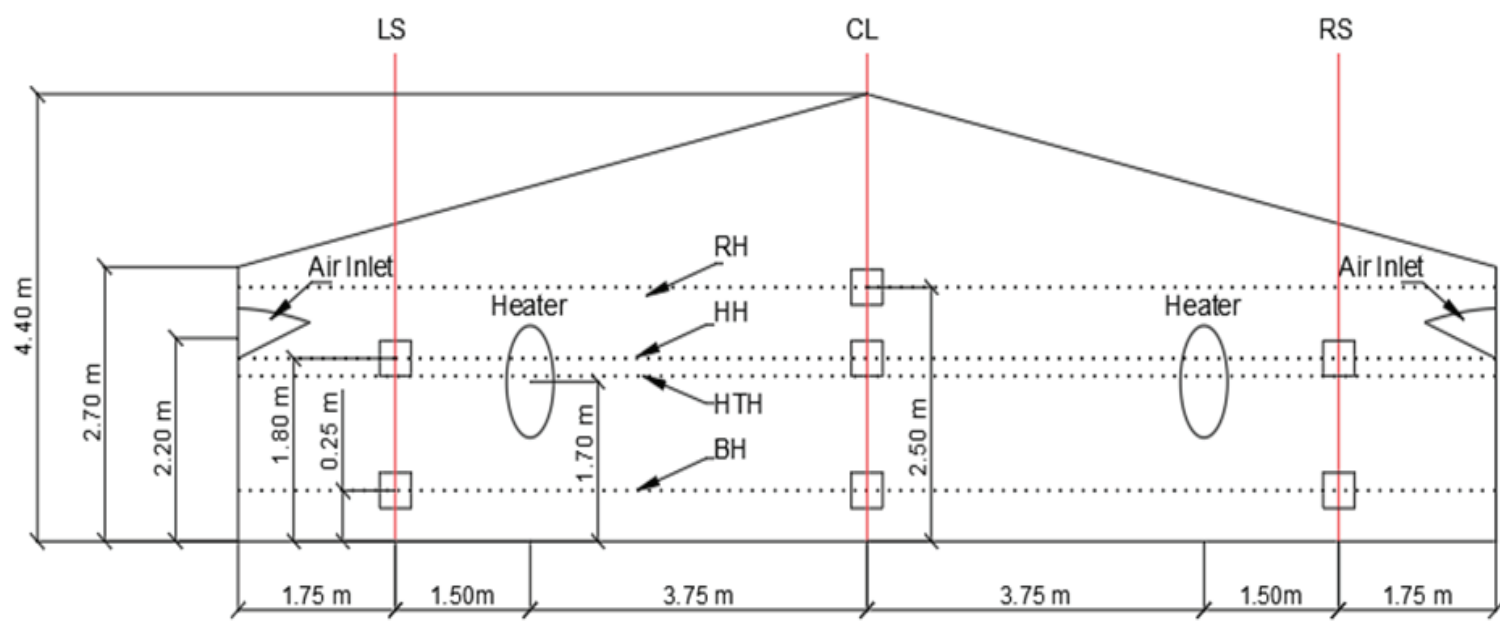

Figure 1- Broiler house geometry and sensor locations 


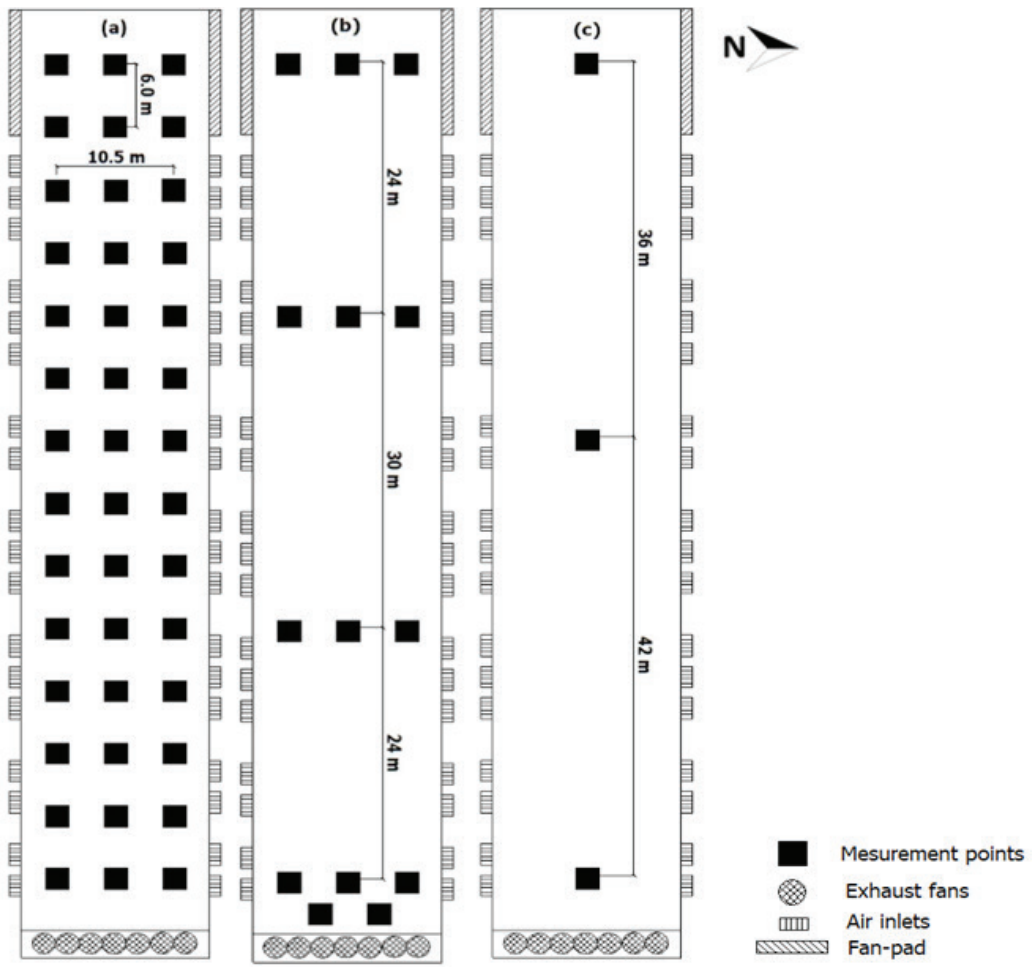

Figure 2- Broiler house measurement points (a), birds' height; (b), human height; (c), roof height



Figure 3- Measurements levels and general views of the broiler house

Tarım Bilimleri Dergisi - Journal of Agricultural Sciences 25 (2019) 440-448 


\subsection{Numerical method}

In numerical analysis, CFD software was used to determine environmental conditions (air temperature, relative humidity and air velocity) within the house. Although several types of CFD software are available in the market, Ansys Fluent, based on finite volume method, is the most popular amongst these. The finite volume method is a discretization method which transforms the partial differential equations from conservation laws to discrete algebraic equations (differential volumes) over finite volumes (or elements or cells) (Eymard et al 2000). The continuity, conservation of momentum (Navier-Stokes law), and the energy equation solved by the software. Detailed information about computational methods can be obtained from Versteeg \& Malalasekera (2007).

In this study, standard k- $\varepsilon$ turbulence model (Launder \& Spalding 1974) was used to represent turbulent flow, predicted air temperature, relative humidity and air velocity distribution in the house. This model is widely preferred for turbulent poultry house simulations, due to its robustness and reliability (Blanes-Vidal et al 2008). AutoCAD (version 2016, Autodesk, San Rafael, Cal., USA) software was used to create $3 \mathrm{D}$ geometry of the broiler house at a scale of 1:1. The geometry was then imported into the software Ansys ${ }^{\circledR}$ Fluent (version 13, Fluent Inc., Lebanon, NH, USA) for development of a mesh. Boundary conditions were defined as follows, for air inlets "velocity-inlet", for fans "pressure outlet" and for walls, roof and floor "wall". The surface temperature of walls, roof, heater and broiler, air relative humidity and air velocity were set as the initial boundary conditions for CFD model according to field measurements as shown in Table 1. The production of total heat by broilers that were $4^{\text {th }}$ weeks of age and having 1624 $\mathrm{g}$ of body weight was estimated using the CIGR (2002) equation.

\subsection{Validation}

The CFD simulation results were validated by comparing with the measured values at the same locations where the sensors were installed. The model fit between measured and predicted values was evaluated by calculating the normalized mean square error (NMSE) where values of NMSE less than 0.25 are accepted as good indicators of fit according to ASTM (2002). NMSE is calculated with the Equation (1) that reads as follows:

$$
N M S E=\frac{1}{N} \sum_{i=1}^{n} \frac{\left(C_{p i}-C_{m i}\right)^{2}}{\left(C_{p m} \times C_{m m}\right)}
$$

Table 1- Initial boundary conditions

\begin{tabular}{lll}
\hline Boundary elements & & Values \\
\hline Surface temperature & Walls & East: $23.20^{\circ} \mathrm{C}$, West: $23.70{ }^{\circ} \mathrm{C}$ \\
& & North: $24.60{ }^{\circ} \mathrm{C}$, South: $23.40{ }^{\circ} \mathrm{C}$ \\
& Roof & $24.90^{\circ} \mathrm{C}$ \\
& Heater & $75.00{ }^{\circ} \mathrm{C}$ \\
& Broiler & $33.40{ }^{\circ} \mathrm{C}$ \\
Air temperature & Outside the building & $11.60{ }^{\circ} \mathrm{C}$ \\
& Inside the building & $27.70{ }^{\circ} \mathrm{C}$ \\
Mass fraction water vapor & Outside the building & 0.00765 \\
Pressure & Fans & $-20 \mathrm{~Pa}$ \\
Velocity & Inlets & $3.34-3.51 \mathrm{~m} \mathrm{~s}^{-1}$ \\
Heat flux & Floor & $137.91 \mathrm{~W} \mathrm{~m}^{-2}$ \\
\hline
\end{tabular}


Where; $C_{p i}$ and $C_{m i}$, predicted and measured values, respectively; $C_{p m}$ and $C_{m m}$, average predicted and measured values, respectively; $N$, the total number of data.

\section{Results and Discussion}

CFD simulation and experimental results of indoor air temperature, relative humidity and velocity distribution are shown in Table 2. Good agreement between simulation results (predicted) and experimental data (measured) were found in the broiler house, since all calculated NMSE values were less than 0.25 according to the ASTM (2002) standards.

\subsection{The indoor air temperature distribution: simulation vs. experiment}

Considering the measurement line $\mathrm{BH}$, higher temperatures were observed along the central line (CL) as compared to the temperatures observed on the left (south side, LS) and right (north side, RS) side of the CL. The presence of two working fans in the middle part of the building affected air movement and temperature distribution in the building. It was observed that birds tended to gather along the CL mostly closer the fan areas, which may have caused the observed increase in air temperature along the
CL, with highest temperatures closer to the fans due to increased sensible heat produced by birds (Figure 4a). The CL temperature averaged 25.70 ${ }^{\circ} \mathrm{C}$ while the LS and RS regions recorded relatively lower temperature with an average of about 24.52 ${ }^{\circ} \mathrm{C}$ These observed results coincide with the temperature gradients found by Xin et al (1994) and Saraz et al (2012).

At $\mathrm{HH}$, temperature near the side walls appeared to be warmer by about $2{ }^{\circ} \mathrm{C}$ than at the $\mathrm{CL}$ of the building due to the presence of heaters at this height (HTH) (Figure 4b).

Data recorded at $\mathrm{RH}$ showed that the indoor temperatures at CL registered relatively little lower temperatures with an average of $24.10^{\circ} \mathrm{C}$ than air temperatures near the walls which had an average temperature of $25.40{ }^{\circ} \mathrm{C}$. This may be attributed again to the presence of heaters near the side walls (Figure 4c).

The fresh cold air entering through side wall inlets must be kept away from the birds as much as possible. Therefore, the fresh air coming in through the inlets should first be directed towards the ceiling to mix with warm air before it reaches the birds. As shown in Figure 4b-c, incoming air from inlets closer to the fans is immediately drawn out by

Table 2- Average \pm standard deviation indoor air temperature $\left({ }^{\circ} \mathrm{C}\right)$, air relative humidity $(\%)$, air velocity $\left(\mathrm{m} \mathrm{s}^{-1}\right)$ and NMSE values

\begin{tabular}{|c|c|c|c|c|c|c|}
\hline \multirow{2}{*}{ Data } & \multicolumn{2}{|c|}{$\begin{array}{l}\text { Height of the birds } \\
(0.25 \mathrm{~m})\end{array}$} & \multicolumn{2}{|c|}{$\begin{array}{l}\text { Height of the human } \\
(1.80 \mathrm{~m})\end{array}$} & \multicolumn{2}{|c|}{$\begin{array}{l}\text { Height of the roof } \\
(2.50 \mathrm{~m})\end{array}$} \\
\hline & $\begin{array}{l}\text { Measured } \\
\text { values }\end{array}$ & $\begin{array}{l}\text { Predicted } \\
\text { values }\end{array}$ & $\begin{array}{l}\text { Measured } \\
\text { values }\end{array}$ & $\begin{array}{l}\text { Predicted } \\
\text { values }\end{array}$ & $\begin{array}{l}\text { Measured } \\
\text { values }\end{array}$ & $\begin{array}{l}\text { Predicted } \\
\text { values }\end{array}$ \\
\hline & \multicolumn{6}{|c|}{ Indoor air temperature $\left({ }^{\circ} \mathrm{C}\right)$} \\
\hline Average & $24.41 \pm 0.95$ & $24.97 \pm 1.02$ & $24.18 \pm 0.71$ & $23.63 \pm 0.95$ & $24.23 \pm 0.90$ & $23.60 \pm 1.11$ \\
\hline \multirow[t]{2}{*}{ NMSE } & 0.049 & & 0.124 & & 0.243 & \\
\hline & \multicolumn{6}{|c|}{ Indoor air relative humidity (\%) } \\
\hline Average & $69.10 \pm 2.39$ & $70.18 \pm 2.69$ & $70.48 \pm 1.85$ & $71.73 \pm 1.66$ & $69.98 \pm 0.90$ & $72.50 \pm 1.44$ \\
\hline \multirow[t]{2}{*}{ NMSE } & 0.108 & & 0.198 & & 0.236 & \\
\hline & \multicolumn{6}{|c|}{ Indoor air velocity $\left(\mathrm{m} \mathrm{s}^{-1}\right)$} \\
\hline Average & $0.98 \pm 0.44$ & $1.05 \pm 0.43$ & $1.05 \pm 0.46$ & $1.19 \pm 0.51$ & $1.26 \pm 0.53$ & $1.19 \pm 0.48$ \\
\hline NMSE & 0.036 & & 0.198 & & 0.037 & \\
\hline
\end{tabular}

Tarım Bilimleri Dergisi - Journal of Agricultural Sciences 25 (2019) 440-448 
the fans taking away with it the hot air. However, temperature is relatively high as the effect of the fans are minimal compared to the fan region. This is due to low static pressure in the region further away from the fans.

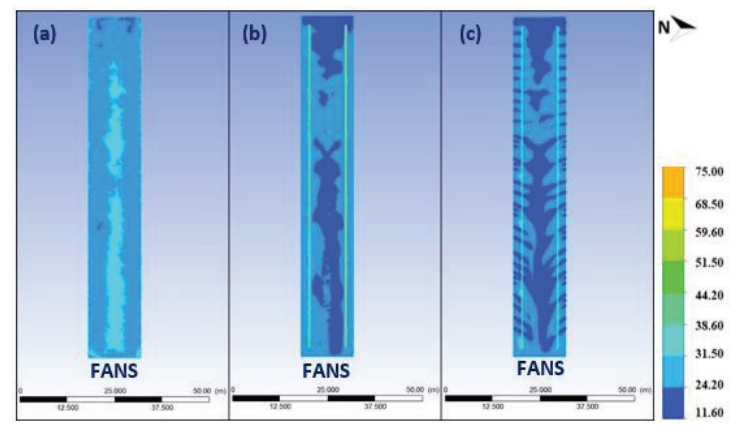

Figure 4- Simulated air temperature $\left({ }^{\circ} \mathrm{C}\right)$ distribution at different measurement positions (a), birds' height; (b), human height; (c) roof height

Lindley \& Whitaker (1996) and Reece \& Lott (1982) indicated that optimum inside temperature of broiler house should be $32.00-33.00^{\circ} \mathrm{C}$ in $1-2$ weeks and $21.00-24.00{ }^{\circ} \mathrm{C}$ in $3-7$ weeks. Considering previous studies, it can be concluded that the temperature of broiler house at $4^{\text {th }}$ week was close to the optimal temperature.

\subsection{The indoor relative humidity distribution: simulation vs. experiment}

The production of moisture at $\mathrm{BH}$ is largely due to birds' respiration and manure exhalations. As shown in Figure 5a, indoor relative humidity at $\mathrm{BH}$ had maximum values (greater than $73.00 \%$ ) along the $\mathrm{CL}$ of the building. The main reason of this can be attributed the preference by birds to gather in the center section of the building. As seen in Figure $5 \mathrm{a}$, the areas close to the fans had relatively small relative humidity values due to the presence of the fans which draw away humidity. On the contrary, the section further away from the fan recorded high concentrations of relative humidity as there is limited fan effect in this region.
The relative humidity distribution at $\mathrm{HH}$ and $\mathrm{RH}$ demonstrated a similar distribution pattern with that of air temperature (Figure 5b-c) Within the regions where air temperature is found to be higher, relative humidity is lower and vice versa. The operation of exhaust fans created a negative static pressure in house which resulted in the withdrawal of moisture from the building.

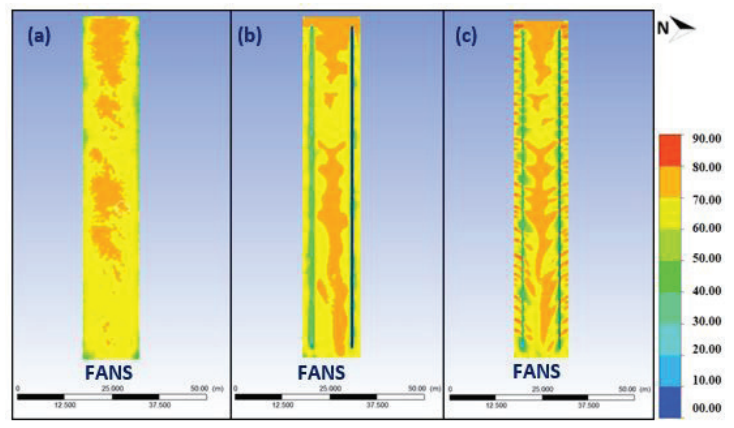

Figure 5- Simulated air relative humidity (\%) distribution at different measurement positions (a), birds' height; (b), human height; (c) roof height

Winn \& Godfrey (1967) recommended that the ideal relative humidity for broilers should remain between $50.00 \%$ and $70.00 \%$ during rearing periods. In this study, the relative humidity level of broiler house at $4^{\text {th }}$ week was close to the optimum relative humidity level.

\subsection{The indoor air velocity distribution: simulation} vs. experiment

As illustrated in Figure 6a-b, air velocity at $\mathrm{BH}$ and $\mathrm{HH}$ is high within the proximity of fans and remained low within the first meter of the building creating stagnant (dead) areas. The fans draw the air from the building, creating a negative pressure (static) situation within the building. The negative pressure within the building pulls the air from outside the higher static pressure difference between the outside and inside, the higher the speed of air entering the house, thus the further the air shoot in.

As seen in Figure 6c, the speed of air flow at roof height is higher at inlets closer to the fans shown 
by red and yellow color streaks than inlets further away from the fans shown by the dark and light blue patches (dead zone). This can be explained by the lower recorded airflow speed $\left(3.34 \mathrm{~m} \mathrm{~s}^{-1}\right)$ at inlets further away from the fans as compared to the higher speed $\left(3.51 \mathrm{~m} \mathrm{~s}^{-1}\right)$ closer to the fans. This may be further aggravated by the presence of heaters that intercept incoming air through the inlets thus causing incomplete airflow mixing in this section. A closer look at all the wind speed measured heights reveal that roof height recorded the highest mean wind velocity and this can be attributed to the positioning of the fans particularly fans' height above the ground.



Figure 6- Simulated air velocity $\left(\mathrm{m} \mathrm{s}^{-1}\right)$ distribution at different measurement positions (a), birds' height; (b), human height; (c) roof height

Dozier et al (2005) cited that birds' age is a factor that contributed to the observed air velocity range of 1.50-3.00 $\mathrm{m} \mathrm{s}^{-1}$. In the current study, measured air velocity values of broiler house at $4^{\text {th }}$ week were under the ideal air velocity values.

\section{Conclusions}

From the previous results and discussions in this study, the following recommendations were arrived at;

The presence of stagnant areas in the region opposite the fans can be corrected by shutting off inlets closer to the fan region and opening inlets further away from the fans which create high static pressure in this region thus allowing better air mixing.
In line with stress areas particularly in the zone further from the fans there is need to introduce a system that enables homogenous air movement and mixing to avert air stagnancy.

CFD provides valuable information to manufacturers and end users on improvement of building designs, the requisite modifications for undertaking more informed decisions and thus more effective broiler production.

\section{Acknowledgements}

The authors acknowledge the financial support of The Scientific and Technological Research Council of Turkey, TUBITAK (Project No: 2150650).

\section{References}

ASHRAE (2009). Fundamentals, SI ed. American Society of Heating, Refrigerating and Air Conditioning Engineers. Atlanta, GA, USA

ASTM (2002). Standard guide (D5157-97) for statistical evaluation of indoor air quality models. ASTM, West Conshohocken, $\mathrm{Pa}$

Awbi H B (2003). Ventilation Systems, Design and Performance. Taylor \& Francis, London and New York, pp. 1-464

Bates P D, Lane S N \& Ferguson R I (2005). Computational Fluid Dynamics: Applications in Environmental Hydraulics. John Wiley \& Sons Ltd, West Sussex, pp. $1-540$

Blanes-Vidal V, Guijarro E, Balasch S \& Torres A (2008). Application of computational fluid dynamics to the prediction of airflow in a mechanically ventilated commercial poultry building. Biosystems Engineering 100(1): 105-116

Bustamante E, García Diego F J, Calvet S, Estellés F, Beltrán P, Hospitaler A \& Torres A G (2013). Exploring ventilation efficiency in poultry buildings: The validation of computational fluid dynamics (CFD) in a cross-mechanically ventilated broiler farm. Energies 6(5): 2605-2623

Bustamante E, García Diego F J, Calvet S, Torres A G \& Hospitaler A (2015). Measurement and numerical simulation of air velocity in a tunnel-ventilated broiler house. Sustainability 7(2): 2066-2085 
CIGR (2002). Heat and moisture production at animal and house level, in: S. Pedersen, K. Sallvik (Eds.) $4^{\text {th }}$ Report of Working Group on Climatization of Animal Houses, Danish Institute of Agricultural Sciences, Horsens, Denmark, pp. 12-13

Deep A, Schwean Lardner K, Crowe T, Fancher B \& Classen H (2010). Effect of light intensity on broiler production, processing characteristics, and welfare. Poultry Science 89(11): 2326-2333

Dozier W, Lott B \& Branton S (2005). Growth responses of male broilers subjected to increasing air velocities at high ambient temperatures and a high dew point. Poultry Science 84(6): 962-966

Eymard R, Gallouët T \& Herbin R (2000). Finite volume methods. Handbook of Numerical Analysis 7: 7131018

Furlan R L, Macari M, Secato E, Guerreiro J \& Malheiros $\mathrm{E}$ (2000). Air velocity and exposure time to ventilation affect body surface and rectal temperature of broiler chickens. The Journal of Applied Poultry Research 9(1): 1-5

Launder B E \& Spalding D (1974). The numerical computation of turbulent flows. Computer Methods in Applied Mechanics and Engineering 3(2): 269-289

Leeson S \& Summers J D (2010). Broiler Breeder Production. Nottingham University Press, Ontario, pp. 1-22

Lindley J A \& Whitaker J H (1996). Agricultural Buildings and Structures. American Society of Agricultural Engineers (ASAE), St Joseph, pp. 565-591

Reece F \& Lott B (1982). Heat and moisture production of broiler chickens during brooding. Poultry Science 61(4): 661-666

Rojano F, Bournet P E, Hassouna M, Robin P, Kacira M \& Choi C Y (2015). Modelling heat and mass transfer of a broiler house using computational fluid dynamics. Biosystems Engineering 136: 25-38
Saraz J A O, Martins M A, Marin O L Z, Damasceno F A \& Velasquez H J C (2012). A review about the use of computational fluid dynamics (CFD) in broiler house. Dyna-Colombia 79(175): 142-149

Song D \& King A (2015). Effects of heat stress on broiler meat quality. World's Poultry Science Journal 71(4): 701-709

USDA (2016). Livestocks and poultry: World markets and trade, United States Department of Agriculture, Foreign agricultural service. In: F. A. S. United States Department of Agriculture (Ed.), Washington, DC, USA, pp. 17-18

Versteeg H K \& Malalasekera W (2007). An Introduction to Computational Fluid Dynamics: The Finite Volume Method. Pearson Education, London, pp. 9-38.

Vizzier Thaxton Y, Christensen K D, Mench J A, Rumley E R, Daugherty C, Feinberg B, Parker M, Siegel P \& Scanes C G (2016). Symposium: Animal welfare challenges for today and tomorrow. Poultry Science 95(9): 2198-2207

Wheeler E F \& Bottcher R (1995). Evaluating mechanical ventilation systems. G-82 Fact Sheet. The Pennsylvania State University, Agricultural and Biological Engineering Department, University Park. State College, pp. 1-3

Winn P N \& Godfrey E F (1967). The effect of humidity on growth and feed conversion of broiler chickens. International Journal of Biometeorology 11(1): 39-50

Xin H, Berry I L, Tabler G T \& Barton T L (1994). Temperature and humidity profiles of broiler houses with experimental conventional and tunnel ventilation systems. Applied Engineering in Agriculture 10(4): 535-542

Xiong Y, Meng Q S, Gao J, Tang X F \& Zhang H F (2017). Effects of relative humidity on animal health and welfare. Journal of Integrative Agriculture 16(8): 1653-1658 